\title{
Halovenus aranensis gen. nov., sp. nov., an extremely halophilic archaeon from Aran-Bidgol salt lake
}

Correspondence M. A. Amoozegar amoozegar@ibrc.ir or amozegar@khayam.ut.ac.ir
A. Makhdoumi-Kakhki, ${ }^{1,2}$ M. A. Amoozegar ${ }^{1,2}$ and A. Ventosa ${ }^{3}$

\author{
${ }^{1}$ Extremophile Laboratory, Department of Microbiology, School of Biology, College of Science, \\ University of Tehran, Tehran, Iran \\ ${ }^{2}$ Microorganisms Bank, Iranian Biological Resource Centre (IBRC), ACECR Tehran, Iran \\ ${ }^{3}$ Department of Microbiology and Parasitology, Faculty of Pharmacy, University of Sevilla, Sevilla, \\ Spain
}

A novel red-pigmented halophilic archaeon, strain $\mathrm{EB} 27^{\top}$, was isolated from Aran-Bidgol salt lake, a hypersaline playa in Iran. Cells of strain EB2 $7^{\top}$ were non-motile and pleomorphic (rods to triangular or disc-shaped). Strain $\mathrm{EB}^{\top} 7^{\top}$ required at least $2.5 \mathrm{M} \mathrm{NaCl}$ and $0.1 \mathrm{M} \mathrm{MgCl}_{2}$ for growth. Optimal growth was achieved at $4 \mathrm{M} \mathrm{NaCl}$ and $0.5 \mathrm{M} \mathrm{MgCl}_{2}$. The optimum $\mathrm{pH}$ and temperature for growth were $\mathrm{pH} 7.5$ and $40{ }^{\circ} \mathrm{C}$; it was able to grow at $\mathrm{pH}$ 6.0-8.0 and 25$50{ }^{\circ} \mathrm{C}$. $16 \mathrm{~S}$ rRNA gene sequence analysis showed that strain EB2 $7^{\top}$ is a member of the family Halobacteriaceae; however, levels of 16S rRNA gene sequence similarity were as low as 90.0, 89.3 and $89.1 \%$ to the most closely related haloarchaeal taxa, namely Halalkalicoccus tibetensis DS12 ${ }^{\top}$, Halosimplex carlsbadense $2-9-1^{\top}$ and Halorhabdus utahensis $\mathrm{AX}-2^{\top}$, respectively. The DNA G $+C$ content of strain EB2 $7^{\top}$ was 61 mol\%. Strain EB2 $7^{\top}$ contained phosphatidylglycerol and phosphatidylglycerol phosphate methyl ester, common phospholipids found in haloarchaea, together with two minor phospholipids. The only quinone present was MK-8(II- $\left.\mathrm{H}_{2}\right)$. Physiological biochemical and phylogenetic differences between strain $\mathrm{EB} 27^{\top}$ and recognized genera of extremely halophilic archaea suggest that this strain represents a novel species in a new genus within the family Halobacteriaceae, for which the name Halovenus aranensis gen. nov., sp. nov. is proposed. The type strain of Halovenus aranensis, the type species of the new genus, is strain EB2 $7^{\top}$ (=IBRC-M $10015^{\top}=$ CGMCC $\left.1.11001^{\top}\right)$
Halophilic archaea which need at least $1.5 \mathrm{M} \mathrm{NaCl}$ for growth are classified within the family Halobacteriaceae in the order Halobacteriales (Grant et al., 2001). The characteristic pink to red pigmentation of haloarchaea permitted their detection early in the 20th century, especially in salted foods (Clayton \& Gibbs, 1927; Harrison \& Kennedy, 1922; Lochhead, 1934). Hypersaline environments, which are widespread worldwide, are a common source for haloarchaea. Advances in molecular techniques and conventional culturing approaches have led to numerous diversity studies in these extreme habitats. In recent decades, many new haloarchaea have been characterized from these environments (Oren, 2008). There are several hypersaline lakes in Iran, both thalassohaline and athalassohaline, as well as artificial crystallizer ponds, which have not been characterized from a microbiological

The GenBank/EMBL/DDBJ accession number for the 16S rRNA gene sequence of strain EB27 ${ }^{\top}$ is $\mathrm{HQ} 197980$.

Three supplementary figures are available with the online version of this paper. standpoint. During a study of the microbial population in one of these salt lakes, Aran-Bidgol, a large number of extremely halophilic archaea were isolated. Here we present the isolation and polyphasic characterization of a novel halophilic archaeal strain that is considered to represent a novel species of a new genus in the family Halobacteriaceae.

Aran-Bidgol salt lake is located in the central desert of Iran at an altitude of $800 \mathrm{~m}$ and $1000 \mathrm{~km}$ from the coast $\left(35^{\circ}\right.$ $70^{\prime} 47^{\prime \prime} \mathrm{N} 51^{\circ} 39^{\prime} 62^{\prime \prime} \mathrm{E}$ ). This playa was formed as a result of deposition of halite sediments over different geological periods. Sediments are dissolved by rainfall during the winter and salt is produced as a result of evaporation during the dry season and subsequently harvested commercially. The predominant salts in the lake are $\mathrm{NaCl}$, $\mathrm{Na}_{2} \mathrm{SO}_{4}, \mathrm{MgCl}_{2}$ and $\mathrm{MgSO}_{4}$ with trace carbonates, and it can be considered as a thalassohaline lake. The $\mathrm{pH}$ of the brine in the lake is neutral (about $\mathrm{pH}$ 7.0) and salinity reaches saturation during the dry season. The water temperature was $38{ }^{\circ} \mathrm{C}$ at the time of sampling. Sampling was carried out in the dry season (July-November 2007) 
and water and sediment samples were collected in sterile plastic containers. Modified growth medium (MGM) with $23 \%$ total salt concentration was used for isolation of micro-organisms from the lake (Dyall-Smith, 2006). This medium contains a $23 \%$ salt mixture prepared from $30 \%$ stock solution, which consists of (per litre): $240 \mathrm{~g} \mathrm{NaCl}$, $35 \mathrm{~g} \mathrm{MgSO}_{4} \cdot 7 \mathrm{H}_{2} \mathrm{O}, 30 \mathrm{~g} \mathrm{MgCl}_{2} \cdot 6 \mathrm{H}_{2} \mathrm{O}, 7 \mathrm{~g} \mathrm{KCl}$ and $1 \mathrm{~g}$ $\mathrm{CaCl}_{2} \cdot 2 \mathrm{H}_{2} \mathrm{O}$, supplemented with $1 \%(\mathrm{w} / \mathrm{v})$ peptone (Merck) and $0.2 \%(\mathrm{w} / \mathrm{v})$ yeast extract (Merck); $1.5 \%(\mathrm{w} /$ v) agar was used for solidified media if necessary. The $\mathrm{pH}$ of media was adjusted to 7.2-7.4 with $2 \mathrm{M}$ Tris-base (Merck). Samples were cultured in 23\% MGM solid medium after preparing the appropriate dilutions in the laboratory. Inoculated plates were incubated at $40{ }^{\circ} \mathrm{C}$ for up to 2 months. After successive cultivation, a pure isolate, designated strain $\mathrm{EB} 27^{\mathrm{T}}$, was obtained. Characterization of this strain was achieved following the minimal standards recommended by Oren et al. (1997) for describing novel taxa of the order Halobacteriales. Haloferax volcanii DSM $3754^{\mathrm{T}}$ was used as a reference strain in subsequent testing in this regard.

Cell morphology and motility were examined with an Olympus BX41 microscope equipped with phase-contrast optics. For photography, drops of exponentially growing liquid cultures were used directly without fixing. Colony morphology was observed on agar medium under optimal growth conditions after incubation at $40{ }^{\circ} \mathrm{C}$ for 14 days. The Gram reaction was determined according to the method outlined by Dussault (1955). Physiological tests were conducted by using liquid or solid ( $1.5 \%$ agar) MGM medium as mentioned above, unless stated otherwise. Liquid cultures were incubated at $40{ }^{\circ} \mathrm{C}$ on a shaking incubator at 200 r.p.m. Growth rates were determined by monitoring the increase in $\mathrm{OD}_{600}$. Growth temperature range was examined in liquid MGM medium from 20 to $60{ }^{\circ} \mathrm{C}$ at $5{ }^{\circ} \mathrm{C}$ intervals. Growth was tested at $\mathrm{pH}$ 5.0-9.0; MES (pH 5-6.5), HEPES (pH 7-8) and CHES (pH 8.5-9) buffers were added at a concentration of $50 \mathrm{mM}$. The requirements for $\mathrm{NaCl}$ and $\mathrm{MgCl}_{2}$ for growth were determined in media containing $0-5 \mathrm{M} \mathrm{NaCl}(0.5 \mathrm{M}$ intervals) or $0-1 \mathrm{M} \mathrm{MgCl}_{2}$ (0.05 $\mathrm{M}$ intervals), respectively.

Acid production from substrates was tested in unbuffered MGM medium and was determined by measuring the initial and final $\mathrm{pH}$ of the medium. The culture was considered positive for acid production if the $\mathrm{pH}$ decreased by at least 1 unit. To test for carbon source utilization, peptone was omitted from MGM medium and yeast extract concentration was reduced to $0.1 \mathrm{~g} \mathrm{l}^{-1}$ (Oren et al., 1997). The ability of strain $\mathrm{EB} 27^{\mathrm{T}}$ to grow anaerobically in the presence of DMSO $\left(5.0 \mathrm{~g} \mathrm{l}^{-1}\right)$ and to ferment arginine $\left(5.0 \mathrm{~g} \mathrm{l}^{-1}\right)$ was tested in MGM medium prepared anaerobically in serum tubes according to the procedures described by Bryant (1972) and Balch \& Wolfe (1976). Growth and gas formation with nitrate as electron acceptor were tested in $10 \mathrm{ml}$ stoppered tubes, completely filled with liquid growth medium to which $\mathrm{NaNO}_{3}\left(5 \mathrm{~g} \mathrm{l}^{-1}\right)$ had been added, and containing an inverted Durham tube (Oren et al., 1997). Tween hydrolysis activity was detected as described by Gutiérrez \& González (1972). Hydrolysis of casein, gelatin and starch was determined as described by Oren et al. (1997). Tests for catalase and oxidase activities were performed as described by González et al. (1978). Production of $\mathrm{H}_{2} \mathrm{~S}$ was tested by growing strain $\mathrm{EB} 27^{\mathrm{T}}$ in MGM liquid medium supplemented with $0.5 \%(\mathrm{w} / \mathrm{v})$ $\mathrm{Na}_{2} \mathrm{~S}_{2} \mathrm{O}_{3}$ (Oren et al., 1997). Tryptone water medium was used for detection of indole production (Smibert \& Krieg, 1994). Antimicrobial sensitivity was determined by the disc diffusion method after spreading the strain on solid MGM medium (Oren et al., 1997).

Cells of strain $\mathrm{EB} 27^{\mathrm{T}}$ were non-motile and pleomorphic (rods to triangles, squares or disc-shaped; Fig. 1) and stained Gram-negative. Colonies formed on solid MGM medium were small (about $1.0 \mathrm{~mm}$ ), convex, round, with an entire edge, shiny and intensely red-pigmented. Strain $\mathrm{EB} 27^{\mathrm{T}}$ was able to grow over a range of $\mathrm{NaCl}$ concentrations from 2.5 to $5 \mathrm{M}$, with optimal growth at $4 \mathrm{M} \mathrm{NaCl}$. Magnesium was required for growth within the range 0.1-1 $\mathrm{M}$ (optimum growth at $0.5 \mathrm{M}$ ). The growth $\mathrm{pH}$ range was $6.0-8.0$ (optimum growth at $\mathrm{pH} 7.5$ ) and the isolate grew at 25$50{ }^{\circ} \mathrm{C}$ (optimum growth at $40^{\circ} \mathrm{C}$ ). Strain $\mathrm{EB} 27^{\mathrm{T}}$ was catalase- and oxidase-positive. It did not hydrolyse gelatin, starch or Tweens 20,40,60 and 80. Acid was produced from D-glucose but not from D-galactose, sucrose, D-fructose, Dxylose, D-mannitol, D-mannose, trehalose, D-arabinose or lactose. Strain $\mathrm{EB} 27^{\mathrm{T}}$ utilized D-glucose and D-galactose as single carbon source but not lactose, L-glycine, L-proline or L-cysteine. The detailed physiological and biochemical characteristics of strain EB2 $7^{\mathrm{T}}$ are given in Table 1 as well as in the genus and species descriptions below.

The genomic DNA of the new isolate was extracted as described by Lam in the Halohandbook (Dyall-Smith, 2006) for haloarchaea and the $16 \mathrm{~S}$ rRNA gene was amplified by using archaeal universal primers 21F (DeLong, 1992) (5'-TTCCGGTTGATCCYGCCGGA-3') and 1492R (5'-GGTTACCTTGTTACGACTT-3') (Lane et al., 1985). PCR products were purified with the DNA purification kit

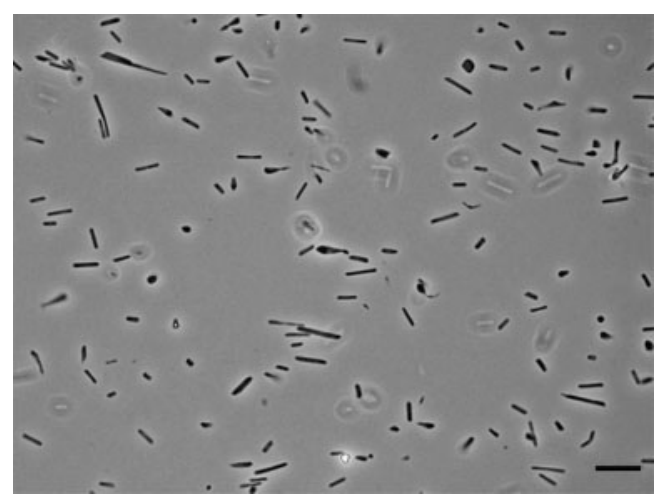

Fig. 1. Phase-contrast photomicrograph of cells of strain EB2 $7^{\top}$. Bar, $10 \mu \mathrm{m}$. 
Table 1. Differential characteristics of strain $E B 27^{\top}$ and strains of type species of closely related genera within the order Halobacteriales

Taxa: 1, strain EB27 ${ }^{\mathrm{T}}$ (data from this study); 2, Halalkalicoccus tibetensis DS12 ${ }^{\mathrm{T}}$ (Xue et al., 2005); 3, Halosimplex carlsbadense 2-9-1 ${ }^{\mathrm{T}}$ (Vreeland et al., 2002); 4, Halorhabdus utahensis AX-2 ${ }^{\mathrm{T}}$ (Wainø et al., 2000); 5, Haloterrigena turkmenica VKM B-1734 ${ }^{\mathrm{T}}$ (Ventosa et al., 1999); and 6, Halobacterium salinarum DSM $3754^{\mathrm{T}}$ (Grant et al., 2001).

\begin{tabular}{|c|c|c|c|c|c|c|}
\hline Character & 1 & 2 & 3 & 4 & 5 & 6 \\
\hline Cell shape & Pleomorphic/rods & Cocci & Rods & Rods & Cocci & Small rods \\
\hline Cell size $(\mu \mathrm{m})$ & $0.6-1.3 \times 4.9-10.7$ & $1-1.5$ & $0.95 \times 5$ & $0.5-1 \times 2-10$ & $1.5-2.0$ & $0.5-1.0 \times 1.0-6.0$ \\
\hline Pigmentation & Red & Orange & Pink to red & Red & Red & Red \\
\hline $\begin{array}{l}\text { Optimum } \mathrm{NaCl} \\
\text { concentration }(\mathrm{M})\end{array}$ & 4 & 3.4 & 4.3 & 4.6 & $3-4$ & $3.4-4.3$ \\
\hline Lysis in distilled water & + & - & + & + & - & + \\
\hline Optimum temperature $\left({ }^{\circ} \mathrm{C}\right)$ & 40 & 40 & $37-40$ & 50 & $30-40$ & 50 \\
\hline \multicolumn{7}{|l|}{ Growth at: } \\
\hline pH 7 & + & - & + & + & + & + \\
\hline pH 10 & - & + & - & - & - & - \\
\hline Nitrate reduction to nitrite & - & + & - & + & + & + \\
\hline DNA G + C content $(\mathrm{mol} \%)$ & 61.0 & 61.5 & 64.4 & 64.0 & 59.8 & 67.1 \\
\hline $\begin{array}{l}\text { 16S rRNA gene sequence } \\
\text { similarity to strain } \mathrm{EB} 27^{\mathrm{T}}(\%)\end{array}$ & 100 & 90.0 & 89.3 & 89.1 & 88.7 & 87.3 \\
\hline
\end{tabular}

(Roche) according to the manufacturer's protocol. The purified PCR products were then electrophoresed on a $1 \%$ agarose gel to check their quality. Ligation of the PCR products with the pGEM-T vector, transformation of Escherichia coli $\mathrm{DH} 5 \alpha$ and selection of the transformants were carried out with the pGEM-T TA cloning kit (Promega) according to the manufacturer's protocol. Several clones were randomly picked and then sequenced by the service of Macrogen Company, South Korea, to determine whether the strain possessed multiple distinct $16 \mathrm{~S}$ rRNA gene sequences. Phylogenetic analysis was performed by using the software package MEGA version 4 (Tamura et al., 2007) after obtaining multiple alignments of the data available from public databases via CLUSTAL $\mathrm{X}$ (Thompson et al., 1997). Clustering was performed with the neighbour-joining (Saitou \& Nei, 1987), maximumparsimony (Fitch, 1971) and minimum-evolution (Rzhetsky \& Nei, 1992) methods. Bootstrap analysis was used to evaluate the tree topology of the neighbour-joining data based on 1000 resamplings (Felsenstein, 1985).

Fifteen almost-complete 16S rRNA gene sequences (each $1440 \mathrm{nt}$ ) of strain $\mathrm{EB} 27^{\mathrm{T}}$ were obtained. Comparisons indicated that this strain has one type of 16S rRNA gene sequence. 16S rRNA gene sequencing showed that strain $\mathrm{EB} 27^{\mathrm{T}}$ is a member of the family Halobacteriaceae; levels of similarity were as low as $90,89.3$ and $89.1 \%$ to its most closely related haloarchaeal taxa, namely Halalkalicoccus tibetensis $\mathrm{DS} 12^{\mathrm{T}}$, Halosimplex carlsbadense $2-9-1^{\mathrm{T}}$ and Halorhabdus utahensis $\mathrm{AX}-2^{\mathrm{T}}$, respectively. Phylogenetic analysis by using the neighbour-joining algorithm revealed that the strain clustered in a separate clade (Fig. 2). This phylogenetic position was also confirmed in the trees generated with the minimum-evolution and maximumparsimony algorithms (see Figs S1 and S2 in IJSEM Online).

The DNA $\mathrm{G}+\mathrm{C}$ content was determined by the HPLC method (Mesbah et al., 1989). The DNA G + C content of strain $\mathrm{EB} 27^{\mathrm{T}}$ was $61.0 \mathrm{~mol} \%$, which is lower than the values reported for Halosimplex and Halorhabdus but similar to that for Halalkalicoccus (Table 1).

Polar lipid composition and respiratory quinones were determined/identified by using the services of the Deutsche Sammlung von Mikroorganismen und Zellkulturen and Dr Brian Tindall (Braunschweig, Germany). Polar lipids were separated by two-dimensional silica gel TLC. Methods, including solvents in each direction and detection reagents, were as described by Hezayen et al. (2001). Strain EB27 contained phosphatidylglycerol, phosphatidylglycerol phosphate methyl ester and two minor phospholipids (Fig. S3). Polar lipid compositions are one of the important differential features in haloarchaeal taxonomy. Non-alkaliphilic haloarchaea contain a variety of glycolipids, whereas haloalkaliphilic archaea have a comparatively simple polar lipid pattern and do not contain any glycolipids (Torreblanca et al., 1986; Kamekura \& Dyall-Smith, 1995). Strain EB27 ${ }^{\mathrm{T}}$, a non-alkaliphilic haloarchaeon, showed a simple pattern of polar lipids and did not contain any glycolipid derivatives. The minor phospholipids associated with this novel strain 


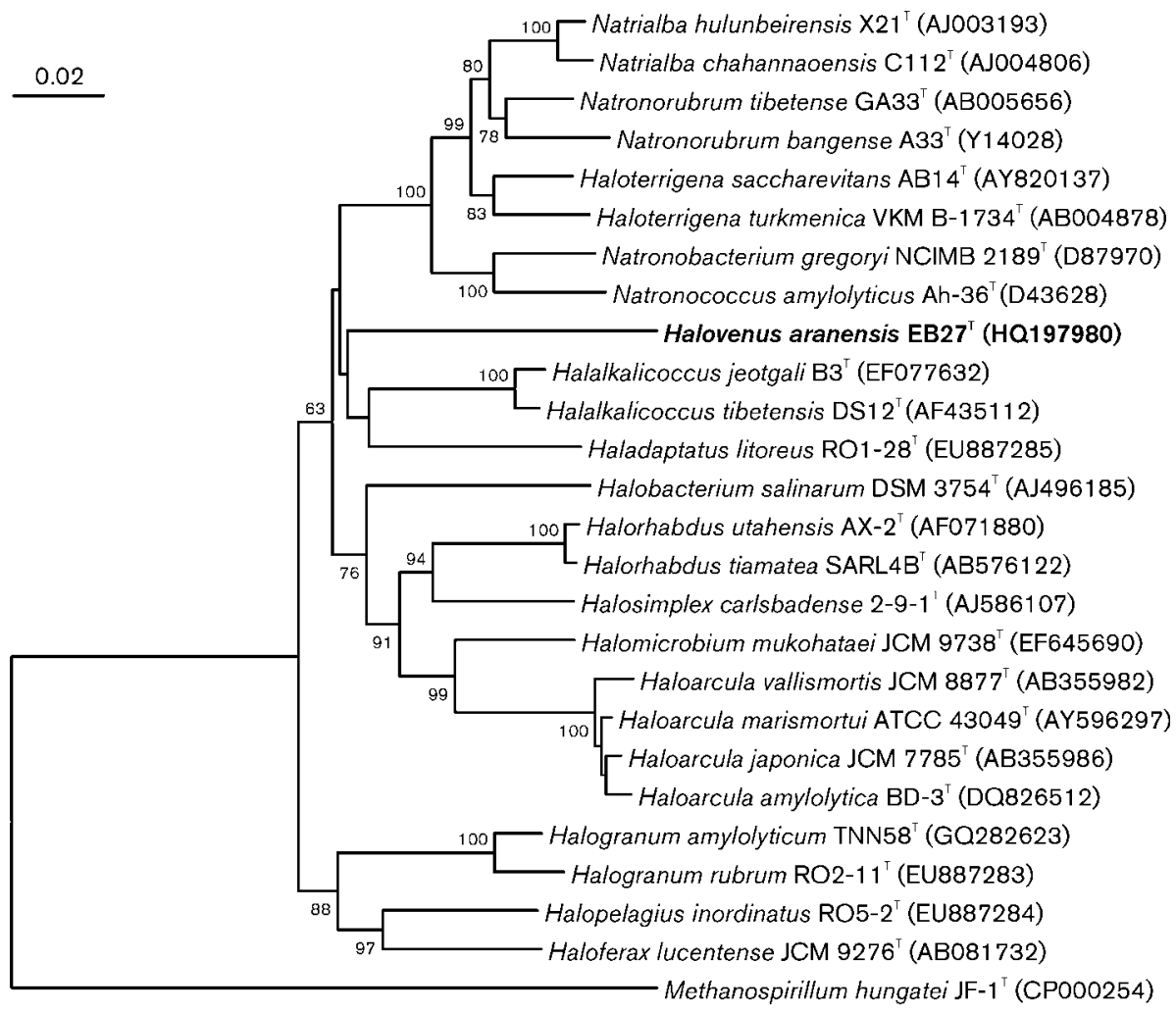

Fig. 2. Neighbour-joining phylogenetic tree based on $16 \mathrm{~S}$ rRNA gene sequences showing the relationship between strain EB27 ${ }^{\top}$ and close relatives within the family Halobacteriaceae. Accession numbers of the sequences are given in parentheses. The sequence of the methanogenic archaeon Methanospirillum hungatei JF-1 ${ }^{\top}$ (CP000254) was used as an outgroup. Numbers at nodes are bootstrap values (percentages of 1000 replicates). Bar, 0.02 substitutions per nucleotide position.

were not detected in the haloalkaliphilic genus Halalkalicoccus, to which it is closely related phylogenetically (Xue et al., 2005). This result indicates a difference between strain $\mathrm{EB} 27^{\mathrm{T}}$ and its closest relatives in the family Halobacteriaceae. Respiratory lipoquinones were analysed as described by Wainø et al. (2000). MK-8(II- $\left.\mathrm{H}_{2}\right)$ was the only respiratory lipoquinone present.

In conclusion, the morphological and physiological properties of the novel isolate, low levels of 16S rRNA gene sequence similarity with members of other genera within the family Halobacteriaceae and the distinctive pattern of polar lipids suggest that strain $\mathrm{EB} 27^{\mathrm{T}}$ represents a novel species of a new genus within the family Halobacteriaceae, for which the name Halovenus aranensis gen. nov., sp. nov. is proposed.

\section{Description of Halovenus gen. nov.}

Halovenus (Ha.lo.ve' nus. Gr. n. hals halos salt; L. fem. n. venus beauty, grace, elegance; N.L. fem. n. Halovenus a salt-loving beauty, reflecting the attractive appearance of colonies).

Cells are non-motile and pleomorphic (rods to triangles, squares or disc-shaped). Gram-stain-negative, strictly aerobic and extremely halophilic. Cells lyse in distilled water. Chemo-organotrophic, growing on a wide range of substrates, including single and complex carbon sources. Strictly aerobic; oxygen is used as the terminal electron acceptor. Cells contain phosphatidylglycerol, phosphatidylglycerol phosphate methyl ester and two minor phospholipids. MK- $8\left(\mathrm{II}-\mathrm{H}_{2}\right)$ is the only lipoquinone present. Phylogenetically related to the genera Halalkalicoccus, Halosimplex and Halorhabdus in the family Halobacteriaceae. The type species is Halovenus aranensis. Hvn. is proposed as the three-letter abbreviation.

\section{Description of Halovenus aranensis sp. nov.}

Halovenus aranensis (a.ra.nen'sis. N.L. fem. adj. aranensis belonging to Aran-Bidgol salt lake, from where the type strain was isolated).

Has the following properties in addition to those given for the genus. Cells are $0.6-1.3 \times 4.9-10.7 \mu \mathrm{m}$ when grown in MGM liquid medium at optimum conditions. Colonies are small (about $1.0 \mathrm{~mm}$ in diameter), shiny and intensely redpigmented. Growth occurs at $\mathrm{NaCl}$ concentrations of 2.55.0 $\mathrm{M}$ (optimum $4.0 \mathrm{M}$ ), at $\mathrm{Mg}^{2+}$ concentrations of $0.2-$ $1.0 \mathrm{M}$ (optimum $0.5 \mathrm{M}$ ), at $\mathrm{pH}$ 6.0-8.0 (optimum $\mathrm{pH}$ 7.5) 
and at $25-50{ }^{\circ} \mathrm{C}$ (optimum $40{ }^{\circ} \mathrm{C}$ ). Catalase- and oxidasepositive. Does not grow under anaerobic conditions with nitrate, arginine or DMSO. Nitrate reduction to nitrite and gas formation from nitrate are not observed. Does not hydrolyse Tweens $20,40,60$ or 80 , casein, gelatin or starch. Utilizes D-glucose and D-galactose as carbon sources for growth but not lactose, L-glycine, L-proline or L-cysteine. Produces acid from D-glucose, but not from D-galactose, sucrose, D-fructose, D-xylose, D-mannitol, D-mannose, trehalose, D-arabinose or lactose. Indole is not produced. $\mathrm{H}_{2} \mathrm{~S}$ is not produced from thiosulfate. Sensitive to ( $\mu \mathrm{g}$ per disc unless otherwise noted) bacitracin (10 U), nitrofurantoin (300), novobiocin (30), polymixin B (100 U), rifampicin (5), streptomycin (10) and anisomycin (30), but resistant to amikacin (30), amoxicillin (10), chloramphenicol (30), erythromycin (15), gentamicin (30), kanamycin (30), tetracycline (30), tobramycin (10), nalidixic acid (30), cephalothin (30), penicillin G (10 U), ampicillin (10) and neomycin (10).

The type strain, EB27 ${ }^{\mathrm{T}} \quad\left(=\mathrm{IBRC}-\mathrm{M} \quad 10015^{\mathrm{T}}=\mathrm{CGMCC}\right.$ $1.11001^{\mathrm{T}}$ ), was isolated from Aran-Bidgol salt lake, Iran. The DNA G + C content of the type strain is $61.0 \mathrm{~mol} \%$ (as determined by HPLC).

\section{Acknowledgements}

We thank J. Euzéby for his help with etymology. This work was supported by grants from the Iranian Biological Resource Centre (IBRC) (MI-1388-01) and the International Foundation for Science (IFS) $(\mathrm{A} / 4527-1)$

\section{References}

Balch, W. E. \& Wolfe, R. S. (1976). New approach to the cultivation of methanogenic bacteria: 2-mercaptoethanesulfonic acid (HS-CoM)dependent growth of Methanobacterium ruminantium in a pressurized atmosphere. Appl Environ Microbiol 32, 781-791.

Bryant, M. P. (1972). Commentary on the Hungate technique for culture of anaerobic bacteria. Am J Clin Nutr 25, 1324-1328.

Clayton, W. \& Gibbs, W. E. (1927). Examination for halophilic microorganisms. Analyst 52, 395-397.

DeLong, E. F. (1992). Archaea in coastal marine environments. Proc Natl Acad Sci U S A 89, 5685-5689.

Dussault, H. P. (1955). An improved technique for staining red halophilic bacteria. J Bacteriol 70, 484-485.

Dyall-Smith, M. L. (2006). The Halohandbook: protocols for haloarchaeal genetics. http://www.haloarchaea.com/resources/halohandbook.

Felsenstein, J. (1985). Confidence limits on phylogenies: an approach using the bootstrap. Evolution 39, 783-791.

Fitch, W. M. (1971). Toward defining the course of evolution: minimum change for a specific tree topology. Syst Zool 20, 406-416.

González, C., Gutiérrez, C. \& Ramirez, C. (1978). Halobacterium vallismortis sp. nov. An amylolytic and carbohydrate-metabolizing, extremely halophilic bacterium. Can J Microbiol 24, 710-715.

Grant, W. D., Kamekura, M., McGenity, T. J. \& Ventosa, A. (2001). Order I. Halobacteriales: the archaea and deeply branching and phototrophic bacteria. In Bergey's Manual of Systematic
Bacteriology, 2nd edn, vol. 1. Edited by G. M. Garrity. New York: Springer.

Gutiérrez, C. \& González, C. (1972). Method for simultaneous detection of proteinase and esterase activities in extremely halophilic bacteria. Appl Microbiol 24, 516-517.

Harrison, F. C. \& Kennedy, M. E. (1922). The red discoloration of cured codfish. Trans $R$ Soc Can Sct III 16, 101-152.

Hezayen, F. F., Rehm, B. H. A., Tindall, B. J. \& Steinbüchel, A. (2001). Transfer of Natrialba asiatica $\mathrm{B}^{\mathrm{T}}$ to Natrialba taiwanensis sp. nov. and description of Natrialba aegyptiaca sp. nov., a novel extremely halophilic, aerobic, non-pigmented member of the Archaea from Egypt that produces extracellular poly(glutamic acid). Int J Syst Evol Microbiol 51, 1133-1142.

Kamekura, M. \& Dyall-Smith, M. L. (1995). Taxonomy of the family Halobacteriaceae and the description of two new genera Halorubrobacterium and Natrialba. J Gen Appl Microbiol 41, 333-350.

Lane, D. J., Pace, B., Olsen, G. J., Stahl, D. A., Sogin, M. L. \& Pace, N. R. (1985). Rapid determination of $16 S$ ribosomal RNA sequences for phylogenetic analyses. Proc Natl Acad Sci U S A 82, 6955-6959.

Lochhead, A. G. (1934). Bacteriological studies on the red discoloration of salted hides. Can J Res 10, 275-286.

Mesbah, M., Premachandran, U. \& Whitman, W. B. (1989). Precise measurement of the $\mathrm{G}+\mathrm{C}$ content of deoxyribonucleic acid by highperformance liquid chromatography. Int J Syst Evol Bacteriol 39, 159167.

Oren, A. (2008). Microbial life at high salt concentrations: phylogenetic and metabolic diversity. Saline Syst 4, 2.

Oren, A., Ventosa, A. \& Grant, W. D. (1997). Proposed minimal standards for description of new taxa in the order Halobacteriales. Int J Syst Bacteriol 47, 233-238.

Rzhetsky, A. \& Nei, M. (1992). A simple method for estimating and testing minimum-evolution trees. Mol Biol Evol 9, 945-967.

Saitou, N. \& Nei, M. (1987). The neighbor-joining method: a new method for reconstructing phylogenetic trees. Mol Biol Evol 4, 406425.

Smibert, R. M. \& Krieg, N. R. (1994). Phenotypic characterization. In Methods for General and Molecular Bacteriology, pp. 607-654. Edited by P. Gerhardt, R. G. E. Murray, W. A. Wood \& N. R. Krieg. Washington, DC: American Society for Microbiology.

Tamura, K., Dudley, J., Nei, M. \& Kumar, S. (2007). MEGA4: molecular evolutionary genetic analysis (MEGA) software version 4.0. Mol Biol Evol 24, 1596-1599.

Thompson, J. D., Gibson, T. J., Plewniak, F., Jeanmougin, F. \& Higgins, D. J. (1997). The CLUSTAL_X windows interface: flexible strategies for multiple sequence alignment aided by quality analysis tools. Nucleic Acids Res 25, 4876-4882.

Torreblanca, M., Rodríguez-Valera, F., Juez, G., Ventosa, A., Kamekura, M. \& Kates, M. (1986). Classification of non-alkaliphilic halobacteria based on numerical taxonomy and polar lipid composition, and description of Haloarcula gen. nov. and Haloferax gen. nov. Syst Appl Microbiol 8, 89-99.

Ventosa, A., Gutiérrez, M. C., Kamekura, M. \& Dyall-Smith, M. L. (1999). Proposal to transfer Halococcus turkmenicus, Halobacterium trapanicum JCM 9743 and strain GSL-11 to Haloterrigena turkmenica gen. nov., comb. nov. Int J Syst Bacteriol 49, 131-136.

Vreeland, R. H., Straight, S., Krammes, J., Dougherty, K., Rosenzweig, W. D. \& Kamekura, M. (2002). Halosimplex carlsbadense gen. nov., sp. nov., a unique halophilic archaeon, with three $16 \mathrm{~S}$ rRNA genes, that grows only in defined medium with glycerol and acetate or pyruvate. Extremophiles 6, 445-452. 
Wainø, M., Tindall, B. J. \& Ingvorsen, K. (2000). Halorhabdus utahensis gen. nov., sp. nov., an aerobic, extremely halophilic member of the Archaea from Great Salt Lake, Utah. Int J Syst Evol Microbiol 50, 183-190.
Xue, Y., Fan, H., Ventosa, A., Grant, W. D., Jones, B. E., Cowan, D. A. \& $\mathrm{Ma}$, Y. (2005). Halalkalicoccus tibetensis gen. nov., sp. nov., representing a novel genus of haloalkaliphilic archaea. Int J Syst Evol Microbiol 55, 2501-2505. 